\title{
The Impact of Time on Productivity in the Digital Transformation of the Economy
}

\author{
Irina Bogatyreva ${ }^{1,{ }^{*}}$, Larisa Ilyukhina $^{1}$, and Natalia Kozhukhova \\ ${ }^{1}$ Samara State University of Economics, 141, Soviet Army Str., 443090, Samara, Russia
}

\begin{abstract}
The paper is devoted to the study of labour productivity growth on the basis of labour hours management as a key resource of any company. Achieving the strategic goals that face the Russian economy requires the formation and implementation of new approaches to solve the problems of labour productivity growth. One of these approaches is effective time resource management. In this regard, the purpose of the study is to develop guidelines to improve productivity, taking into account the digital economy requirements on the basis of time resource management. Data collection monitoring and information study on the use of time resources in the surveyed enterprises, structure of labour hours costs and causes of losses allowed the authors to obtain reliable results of the study and to formulate reasonable conclusions. The authors developed a setup diagram of labour productivity increase due to the effective use of time resource. They determined the sequence of stages, specificated them, and established their relationship. The paper presents example of calculating possible productivity growth due to better use of working hours for one of the Samara enterprises and structures software products to account, analyse and evaluate the company's time resource with their functionality description.
\end{abstract}

\section{Introduction}

The long-term strategy of the Russian economy development sets high parameters of economic growth rates not less than $5 \%$ of gross domestic product annually that depend on growth rates of labour productivity. However, the existing potential is not fully used. In recent years, there has been a slowdown in economic growth. In 2017, the labour productivity level in the Russian economy, from the corresponding US indicator, was about $36 \%$, Germany - 37\%, Luxembourg - 27\%, Japan - 54\% [1]. Thus, the growth rate of labour productivity is on average no more than $1.3 \%$ per year, which is quite low. This rate cannot provide the necessary economic growth in Russia.

Under the conditions of financial resources, there is updating and modernization restraint of production material and technical that is the main growth driver of labour productivity. Nevertheless, productivity growth can be achieved not only through technical and technological innovations, but also through other low-cost but no less important mechanisms that can give a significant effect when using existing productive assets. The question is about activation of socio-economic and organizational factors of labour

* Corresponding author: scorpiony70@mail.ru 
productivity. The activity of the socio-economic group of factors is aimed at effective management of the human component of production, and organizational factors should lead to improve the labour organization and regulation including time losses reduction. The implementation of all these factors allows to increase the workers' productivity in a short term without any additional funding. Effective time management, as one of the most important resources of the company, is a key mechanism to meet strategic challenges in the Russian economy, such as labour productivity growth in Russian enterprises by at least $30 \%$ in 2025 . Under current economic conditions of the Russian economy development, the most urgent issues are the formation of new approaches to solve problems of labour productivity on the basis of time resource management, using modern information systems and software products.

The purpose of the study is to develop methodical guidelines to solve the problems of labour productivity increase, taking into account the requirements of the digital economy on the basis of time resource management.

To achieve this goal, the following tasks were solved in the study: the authors developed a setup diagram of labour productivity increase through better use of the time resource, presented the algorithm to evaluate the impact of the company's time resource on the employees' productivity, and structured modern domestic information systems and software products for accounting, analysis and evaluation of the company's time resource.

\section{Literature review}

Among the factors and conditions that determine the labour productivity level and dynamics, an important role belongs to labour hours management as the main resource of the company. The analysis of time resource use and labour productivity correlation is of interest to national and foreign scientists [2-3]. Time management becomes the subject of a number of scientific studies. Many economists think that there is a close relationship between the level of working time use and labour productivity [4]. Reduction of any kind of losses including time leads to minimize production costs, add value to the company, and increase its activities efficiency. This is one of the well-known principles of the lean production concept that still has not lost its relevance. This is confirmed by numerous scientific studies in this area [5-8].

The analysis of the surveyed companies shows that undisciplined employees and poor work organization are frequent causes of time losses in national enterprises. It is obvious that with a decrease in labour misconduct and rationalization in labour processes and practices, staff productive time increases. This leads to labour productivity growth.

Some studies show the negative impact of working hours lengthening on human performance [9], human health [10], and occupational injury rates [11]. This can be neutralized by the introduction of flexible labour hours, when the employee can independently determine the working hours in shifts [12].

Collecting information on the time resources use in the company and its processing is quite time-consuming process. Therefore, today, foreign and domestic IT-companies offer a large variety of automated directory and documentation systems and software products to collect and process information. Unfortunately, they all have their advantages and disadvantages. A universal information system for effective time resources management has not yet been developed. Thus, despite the great importance of researches on the theory and practice of time resource management, many issues remain poorly researched and unresolved.

\section{Methodology of research}


Labour productivity increase on the basis of time resource management involves the study of the content, sequence of stages of the process under study, determining of their relationship, as well as the analysis and evaluation of the time use by the company's personnel. All these items are reflected in the authors setup diagram to increase labour productivity through better use of time resources (Fig. 1).

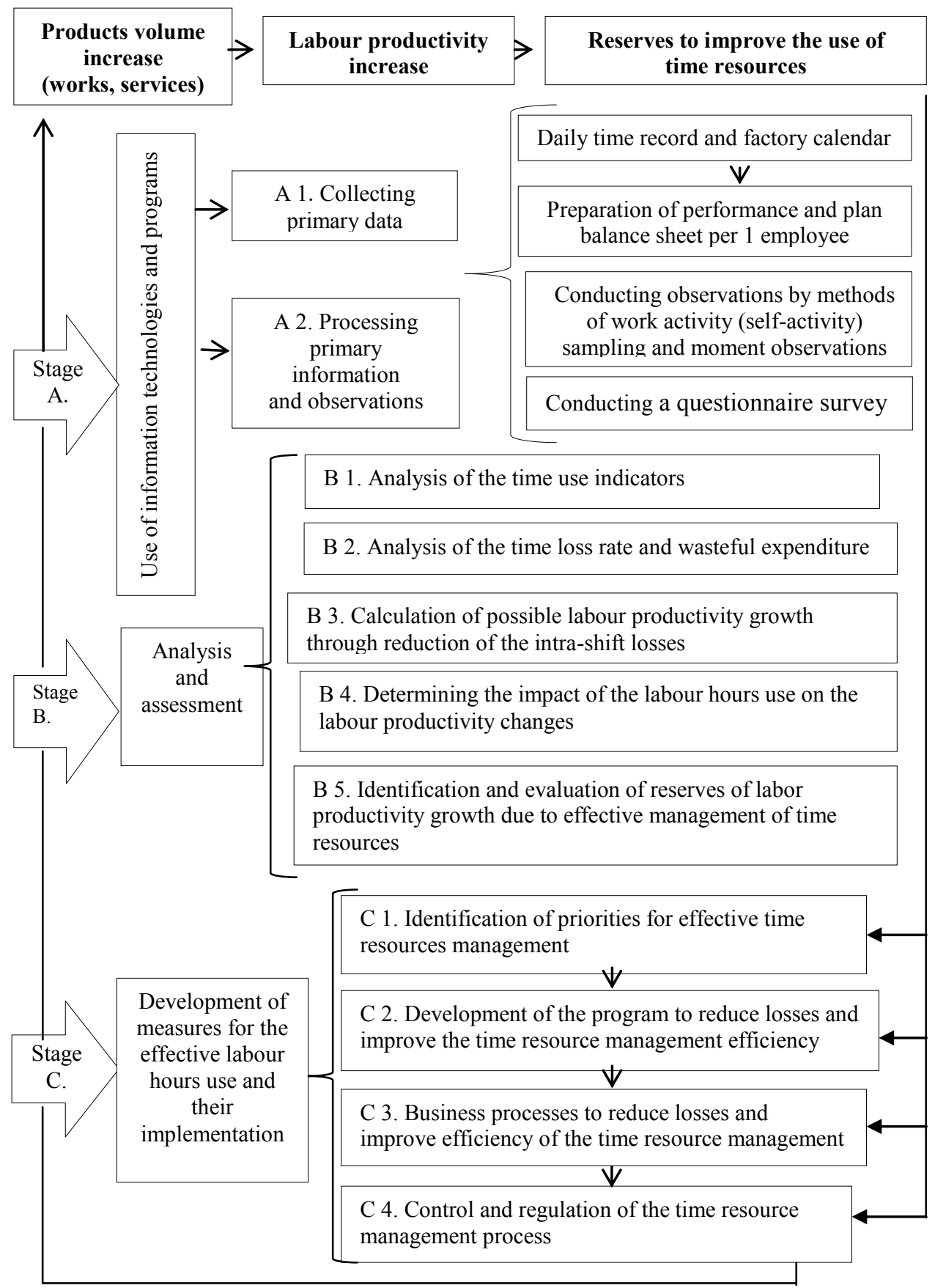

Fig. 1. Stage segmentation of labour productivity inrease due to the effective time resource use. 
The first stage consists of collecting and processing primary data and observations on the labour hours elements, costs, and its losses. In order to identify reserves that can maximize labour productivity, timelines are made up, and they serve as information sources for further analysis of the time structure and characteristics of its elements. In the practice of domestic enterprises, the balance method is supplemented by the work activity or selfactivity sampling for a more complete and detailed study of labour hours.

At the stage of collecting and processing the observation results, the use of complex automated systems operating in a single information space of the enterprise can significantly reduce time spending on processing, develop the qualitative analysis of the work activity or self-activity sampling, and identify reserves. There are modern software products for daily performance record in foreign and domestic practice (Table 1).

Table 1. Characteristics of the modern software products to evaluate labour hours.

\begin{tabular}{|l|l|l|}
\hline \multicolumn{1}{|c|}{ Item } & \multicolumn{1}{|c|}{ Characteristics } & \multicolumn{1}{|c|}{ Price } \\
\hline StaffCop & $\begin{array}{l}\text { The program has the surveillance over employees function. } \\
\text { It analyzes, blocks and alerts of unproductive activities. It } \\
\text { can prohibit (allow) downloading files to external media. } \\
\text { The service takes screenshots of desktops and } \\
\text { correspondence, and notifies the head of violations. }\end{array}$ & $\begin{array}{l}\text { P-25 computers, } \\
200 \text { rubles per 1 user }\end{array}$ \\
\hline $\begin{array}{l}\text { Time } \\
\text { Doctor }\end{array}$ & $\begin{array}{l}\text { Online program monitors the employees' behavior at the PC. } \\
\text { There is a function of controlling the time spent on a } \\
\text { particular job (payroll function). }\end{array}$ & $\begin{array}{l}\text { \$10 subscription per 1 } \\
\text { user }\end{array}$ \\
\hline $\begin{array}{l}\text { Yaware } \\
\text { Time } \\
\text { Tracker }\end{array}$ & $\begin{array}{l}\text { The program includes monitoring of programs, sites and } \\
\text { productivity analysis, and keeps record of working hours. It } \\
\text { records violations. }\end{array}$ & $\begin{array}{l}450 \text { rubles for } \\
\text { monthly subscription } \\
\text { per 1 user }\end{array}$ \\
\hline Kickidler & $\begin{array}{l}\text { The program controls employee's performance. Time tracker } \\
\text { allows to control "open windows" on the desktop. According } \\
\text { to the data obtained, the program creates the employee's } \\
\text { dynamics. }\end{array}$ & $\begin{array}{l}500 \text { rubles for } \\
\text { monthly subscription } \\
\text { and 10,000 rubles for } \\
\text { perpetual license }\end{array}$ \\
\hline Namely & $\begin{array}{l}\text { The program operates by means of cloud technologies. It } \\
\text { allows to simplify and speed up payroll and to determine the } \\
\text { exact amount of labour hours. The personal account has a } \\
\text { function of salary increase under certain conditions. }\end{array}$ & $\begin{array}{l}\text { The price is set on a } \\
\text { case-by-case basis }\end{array}$ \\
\hline
\end{tabular}

The best option is to buy the program StaffCop. For a small price, the program has time control, analysis tools (report designer, threat analysis, anomaly detector, daily performance record, and printer usage time-sheet), locks (process start blocking, website access blocking, and USB device blocking), keylogger function, and online tracing. To connect, simply select the computer in the list and click "remote connection».

The second stage includes the analysis and evaluation of the indicators of the labour hours use, time losses and wasteful expenditure (Fig. 2). The third stage is devoted to the development of practical recommendations for the effective labour hours use and their implementation. When developing specific measures to improve the labour hours use, it is necessary to take into account the specifics of the staff activities in the organization, time losses, and wasteful expenditure. 


\section{B 1. Analysis of indicators of the labour hours use}

$$
\begin{gathered}
\text { Labour utilization rate (Kirv): } \\
\text { Kirv }=\frac{T p z+T o p+T o b s+T o t l}{T s m} * 100,
\end{gathered}
$$

where Tsm is daily working hours, min; Tpz (Top, Tobs) is setup time (operating time and time for workplace servicing, min); Totl is time for rest and personal needs, min.

The rate of labour hours loss due to a violation of the normal course of the organizational process (Kpnt) and labour misconduct (Kpnd):

$$
\text { Kpnt }=\frac{\text { Tpnt }}{\text { Tsm }} * 100, \text { Kpnd }=\frac{\text { Tpnd }}{\text { Tsm }} * 100,
$$

where Tpnt (Tpnd) is loss of time due to organizational and technical reasons (labour misconduct), min.

\section{B 2. Analysis of the causes of loss and time wasteful expenditure.}

Determination of losses rate, causes, and time wasteful expenditure

\section{B 3. Calculation of labour productivity growth due to reduction of intra-shift losses.}

Labour productivity growth due to elimination of intra-shift losses $(\Delta \mathrm{PT})$ :

$$
P T=\frac{\operatorname{Top}(n)-\operatorname{Top}(f)}{\operatorname{Top}(f)} * 100,
$$

where $\operatorname{Top}(n, f)$ is regulatory and real values of operational time, $\min$.

B 4. Analysis of the influence degree of the labour hours use on labour productivity.

B 5. Identification and evaluation of reserves of labor productivity growth due to effective time resources management.

Labour productivity growth due to effective labour time reserve use (IPTfvts (IPTfvv)):

$$
\text { IPTfvts }(I P T f v v)=\frac{F v t s n(F v v n)-P v t s p l(P v v p l)}{F v t s n(F v v n)-P v t s f(P v v f)} \text {, }
$$

where Fvtsn (Fvvn) is day-long (intra-shift) labour time reserve for 1 employee per year, days (hours); Pvtspl (Pvvpl) is day-long (intra-shift) time losses for 1 employee per year in the planning period, days (hours); Pvtsf (Pvvf) is day-long (intra-shift) losses of labour hours for 1 employee per year in the accounting period, days (hours).

Fig. 2. Evaluation of the impact of labour hours on productivity.

For example, reducing the number of absenteeism for illness reasons involves a set of measures related to the annual medical employees' examination in order to identify occupational diseases, improve sanitary-hygienic and psychophysiological working conditions, develop the work ergonomic aspects, carry out the systematic instruction on safety and labour protection, and others. 


\section{Results}

The object of the research was the brigade of 5 workers of the emergency-recovery section of one of Samara enterprises replacing stop-regulating valves with a diameter of $500 \mathrm{~mm}$. Group photograph of working time was being carried out for 3 days. The fixation of all the actions of the working brigade on a previously prepared observation sheet during the entire observation period was carried out by the equal interval (10 minutes) method. According to the results of the observations, the average indicators of the same-time working time costs were calculated for each employee of the brigade per working day (Table 2) and the total actual balance was compiled (Table 3). According to the actual working time balance, the use of working time of the brigade was calculated: working time use ratio $(89.5 \%)$, the ratios for organizational and technical reasons $(7.1 \%)$ and due to violations of labour discipline (3.4). The high proportion of preparatory and final time $(41.7 \%)$ is due to the traveling nature of the work, the specifics of its performance. Significant losses of time $(10.4 \%)$ are caused by organizational and technical reasons (waiting and delays in work).

Table 2. Factual Working Time Balance for Each Worker.

\begin{tabular}{|c|c|c|c|c|c|c|c|c|c|c|}
\hline \multirow{2}{*}{$\begin{array}{l}\text { Working } \\
\text { time costs }\end{array}$} & \multicolumn{2}{|c|}{$\begin{array}{l}\text { The first } \\
\text { worker }\end{array}$} & \multicolumn{2}{|c|}{$\begin{array}{c}\text { The second } \\
\text { worker }\end{array}$} & \multicolumn{2}{|c|}{$\begin{array}{l}\text { The third } \\
\text { worker }\end{array}$} & \multicolumn{2}{|c|}{$\begin{array}{c}\text { The fourth } \\
\text { worker }\end{array}$} & \multicolumn{2}{|c|}{$\begin{array}{l}\text { The fifth } \\
\text { worker }\end{array}$} \\
\hline & $\begin{array}{c}\text { minut } \\
\text { es }\end{array}$ & $\%$ & $\begin{array}{c}\operatorname{minu} \\
\text { tes }\end{array}$ & $\%$ & $\begin{array}{c}\text { minu } \\
\text { tes }\end{array}$ & $\%$ & $\begin{array}{c}\text { minute } \\
\mathrm{S}\end{array}$ & $\%$ & $\begin{array}{c}\operatorname{minu} \\
\text { tes }\end{array}$ & $\%$ \\
\hline OP & 197 & 34 & 210 & 37 & 230 & 40 & 207 & 36,1 & 210 & 37 \\
\hline $\mathrm{PF}$ & 240 & 42 & 243 & 42 & 240 & 42 & 226 & 39,4 & 243 & 42 \\
\hline $\mathrm{M}$ & 52 & 9,0 & 53 & 9,2 & 32 & 5,5 & 53 & 9,2 & 53 & 9,2 \\
\hline RPN & 17 & 3,0 & 17 & 3,0 & 17 & 3,0 & 17 & 3,0 & 17 & 3,0 \\
\hline NDEB & 47 & 8,3 & 37 & 6,5 & 37 & 6,5 & 37 & 6,5 & 37 & 6,5 \\
\hline LDVB & 20 & 3,7 & 13 & 2,3 & 17 & 3,0 & 33 & 5,8 & 13 & 2,3 \\
\hline Total & 573 & 100 & 573 & 100 & 573 & 100 & 573 & 100 & 573 & 100 \\
\hline
\end{tabular}

Source: compiled by the authors.

Table 3. The Time Balance of the Average Worker of the Brigade.

\begin{tabular}{|c|c|c|c|c|c|}
\hline \multirow{2}{*}{ Working time costs } & \multirow{2}{*}{ Index } & \multicolumn{2}{|c|}{ Factual } & \multicolumn{2}{c|}{ Normative } \\
\cline { 5 - 7 } & & minut & $\%$ & minut & \multirow{2}{*}{ es } \\
\hline Preparatory-final time & PF & 239 & 41,7 & 178 & 31 \\
\hline Operative time (job related work) & OP & 209 & 36,5 & 361 & 63 \\
\hline Working place maintenance time & M & 48 & 8,4 & 14 & 2,4 \\
\hline Time for rest and personal needs & RPN & 17 & 3,0 & 11 & 2,0 \\
\hline Breaks not dependent on employees & NDEB & 41 & 7,1 & 9 & 1,6 \\
\hline Breaks caused by labour discipline violations & LDVB & 19 & 3,3 & - & - \\
\hline Total & & 573 & 100 & 573 & 100 \\
\hline
\end{tabular}

Source: compiled by the authors.

According to the results of expert estimation taking into account that the work demands moving to different places, standards were established for preparatory and final work (178 minutes), workplace maintenance (4\%) and for leisure and personal needs (3\%). Due to the elimination of loss of working time during the shift, labour productivity increases by $72.7 \%$.

Determination of the value of reserves for the increase of labour productivity due to effective use of time was carried out by comparing the available fund of working time at the enterprise with the factual working time (Table 4). 
Table 4. The calculation of the reserves for labour productivity (LP) increase due to better use of working time.

\begin{tabular}{|c|c|c|c|c|c|c|c|}
\hline \multirow{3}{*}{ Indicators } & \multirow{2}{*}{\multicolumn{2}{|c|}{ Nominal fund }} & \multicolumn{4}{|c|}{ Time losses } & \multirow{3}{*}{$\begin{array}{l}\text { Labour } \\
\text { productivity } \\
\text { increase } \\
\text { reserves }\end{array}$} \\
\hline & & & \multicolumn{2}{|c|}{$\begin{array}{l}\text { According to } \\
\text { the plan }\end{array}$} & \multicolumn{2}{|c|}{ Actually } & \\
\hline & Abs & $\%$ & Abs & $\%$ & Abs & $\%$ & \\
\hline $\begin{array}{l}\text { Full-day time fund of } \\
\text { one worker per year, } \\
\text { days }\end{array}$ & 247 & 100 & 32 & 12,9 & 43,9 & 17,8 & $5,86 \%$ \\
\hline $\begin{array}{l}\text { Shift time fund of one } \\
\text { worker, hours }\end{array}$ & 8 & 100 & 0,07 & 0,9 & 0,12 & 1,5 & $0,63 \%$ \\
\hline $\begin{array}{l}\text { General fund of } \\
\text { working time per } \\
\text { worker per year, } \\
\text { hours }\end{array}$ & 1976 & 100 & 271,1 & 13,7 & $\begin{array}{c}375 \\
6\end{array}$ & 19,0 & $6,5 \%$ \\
\hline
\end{tabular}

Source: compiled by the authors.

Thus, the results of the study show that one of the promising reserves for the increase of labour productivity at Russian enterprises that do not require additional funding and allow increasing of the efficiency of personnel during the shortest period of time, is to increase the efficiency of working time use.

\section{Discussion}

The development of new information technologies and their implementation in the labour rating, including evaluation of the efficiency of the labour hours use in the organization, impose new requirements to solve problems associated with the labour productivity growth on the basis of time resource management. In this regard, the subject of the study is the formation of methodic positions to increase productivity in the digital economic modernization, based on the efficiency of the time resources use. Despite the fact that the scientific literature pays enough attention to these problems, there is no consensus among practitioners to solve them. Therefore, the following questions are of our particular interest: are there any universal methodic approaches to solve the problems of labour productivity growth on the basis of effective management of the enterprise's time resource under new economic conditions in the Russian economy; what is the sequence of a comprehensive assessment of the impact of the labour hours use, as the most important resource of the company, on labour productivity; what kinds of information technologies and software products can reduce the activity content to account, analyse and evaluate the company's time resource?

Today, there is an objective need to systematize productivity management tools and identify those that can be applied in the short term and with minimal costs by identifying intra-production reserves.

The main factors of the labor productivity in these conditions are the application of innovations in the production [13]; the policy of allocating funds for information technologies at the company level [14]; the state of labor rationing at the enterprise; the automation of processes that reduces the probability of errors in the production because of the human factor [15]; the work standardization; the reduction of working time losses. 


\section{Conclusions}

Effective time resource management is fundamental to the Russian enterprises development in the digital economy. It provides labour productivity growth in a short term by eliminating various types of losses. It is for this reason that it is necessary to continue studying the labour hours activity and management as a key resource of any company with the broad participation of scientists and practitioners. Thus, it is important to develop a comprehensive system of labour hours management, which is an important direction to increase labour productivity in enterprises under modern conditions.

Generalization, systematization and actualization of best practices of the Research Institute of Labour and a number of domestic scientists on labour productivity growth under modern technologies are reflected in the results of the study. In the paper, the authors presented a sequence of stages to increase labour productivity through labour hours rationalization, specificated the content of each stage, determined their relationships and calculation formulae, and defined the features of modern software products that can significantly reduce the activity content on accounting and analysis of labour hours.

\section{References}

1. I. Bogatyreva, M. Simonova, E. Privorotskaya, E3S Web of Conferences, 91 (08022) (2019) DOI: 10.1051/e3sconf/20199108022

2. I.V. Bogatyreva, L.A. Ilyukhina, M.V. Simonova and N.V. Kozhukhova, SHS Web of Conferences, 62 (06002) (2019) DOI:10.1051/shsconf $/ 20196206002$

3. G. Espinosa-Garza, I. Loera-Hernández, N. Antonyan, Procedia Manufacturing, 13, 1003-1010 (2017) DOI: 10.1016 / j.promfg.2017.09.100

4. S. Park, N. Yaduma, A. J. Lockwood, A. M. Williams, Annals of Tourism Research, 59, 93-112 (2016) DOI: 10.1016 / j.annals.2016.04.006

5. P. Martínez-Jurado, J. Moyano-Fuentes, Production Planning \& Control, 25(4), 332345 (2012) DOI: 10.1080 / 09537287.2012.692170

6. A. Pearce, D. Pons, T. Neitzert, Operations Research Perspectives, 5, 94-104 (2018) Doi.org/10.1016/j.orp.2018.02.002

7. R.J. Schonberger, Business Horizons, 62(3), 359-371 (2019) DOI: 10.1016/j.bushor.2019.01.004

8. K.V. Belysh, Russian Journal of Innovation Economics, 8(3), 513-530 (2018)

9. M. Collewet, J. Sauermann. Labour Economics, 47, 96-106 (2017) DOI:10.1016/j.labeco.2017.03.006

10. K. Cygan-Rehm, C. Wunder., Labour Economics, 53, 162-171 (2018) DOI:10.1016/j.labeco.2018.05.003

11. J. Lee, Y.-K. Lee, Labour Economics, 40, 25-36 (2016) Doi.org/10.1016/j.labeco.2016.02.004

12. M. Beckmann, T. Cornelissen, M. Kräkel, Journal Of Economic Behavior \& Organization, 133, 285-302(2017) DOI:10.1016/j.jebo.2016.11.013

13. S. Kurt, Ü. Kurt, Procedia - Social and Behavioral Sciences, 195(3), 1295-1302 (2015) DOI:10.1016/j.sbspro.2015.06.296

14. H. Chun, J.-W. Kim, J. Lee, Research Policy, 44(5), 999-1016 (2015) DOI:10.1016 / j.respol.2014.11.007 
15. M. Jahangiri, N. Hoboubi, A. Rostamabadi, S. Keshavarzi, A.A. Hosseini, Safety and Health at Work, 7(1), 6-11 (2016). Doi.org / 10.1016/j.shaw.2015.06.002 